\title{
Variants of Genes Involved in Metabolism of Folate Among Patients with Breast Cancer: Association of TYMS 3R Allele with Susceptibility to Breast Cancer and Metastasis
}

\author{
Zohreh Rahimi*1,2 iD, Maryam Bozorgi Zarini ${ }^{1}$, Ziba Rahimi ${ }^{1}$, Ebrahim Shakiba*2, Asad Vaisi-Raygani ${ }^{3}$, \\ Mohammad Taher Moradi ${ }^{1}$, Kheirolah Yari ${ }^{1}$ \\ 1. Medical Biology Research Center, Kermanshah University of Medical Sciences, Kermanshah, Iran \\ 2. Department of Clinical Biochemistry, Medical School, Kermanshah University of Medical Sciences, Kermanshah, Iran \\ 3. Fertility and Infertility Research Center, Kermanshah University of Medical Sciences, Kermanshah, Iran
}

\begin{tabular}{|c|c|}
\hline KEYWORDS & ABSTRACT \\
\hline $\begin{array}{l}\text { Breast cancer; } \\
\text { Thymidylate synthase; } \\
\text { Methionine synthase; } \\
\text { Methionine synthase reductase; } \\
\text { Polymorphism; } \\
\text { Metastasis }\end{array}$ & $\begin{array}{l}\text { Background \& Objective: Breast cancer (BC) is known to be the most prevalent cancer } \\
\text { among women. One-carbon metabolism disturbance might play an important role in the } \\
\text { etiology of BC. The present study aimed to investigate the thymidylate synthase (TYMS), } \\
\text { 5-methyltetrahydrofolate-homocysteine methyltransferase (MTR), and methionine } \\
\text { synthase reductase (MTRR) variants as good candidates for studying the role of genetic } \\
\text { variants of folate metabolizing enzymes in the risk of BC. }\end{array}$ \\
\hline 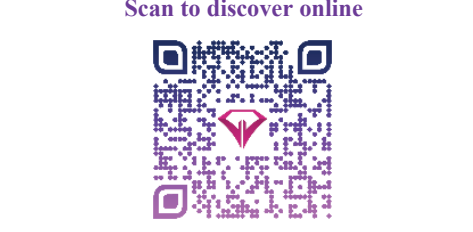 & $\begin{array}{l}\text { Methods: The present case-control study includes } 100 \mathrm{BC} \text { patients and } 141 \text { healthy females. The } \\
\text { TYMS 2R/3R (rs34743033), MTR c. } 2756 \mathrm{~A}>\mathrm{G} \text { (rs1805087), and MTRR c.66A }>\mathrm{G} \text { (rs1801394) } \\
\text { variants were detected by polymerase chain reaction (PCR), PCR-restriction fragment length } \\
\text { polymorphism (RFLP), and a designed amplification-refractory mutation system (ARMS) } \\
\text { method, respectively. }\end{array}$ \\
\hline $\begin{array}{l}\text { Main Subjects: } \\
\text { Cytogenetics }\end{array}$ & $\begin{array}{l}\text { Results: The } 3 \mathrm{R} \text { allele of } T Y M S \text { enhanced the risk of } \mathrm{BC} \text { by } 2.84 \text {-fold }(P<0.001) \text {. In the } \\
\text { presence of } T Y M S 3 \mathrm{R} / 3 \mathrm{R} \text {, compared to TYMS } 2 \mathrm{R} / 3 \mathrm{R} \text {, there was a trend toward }\end{array}$ \\
\hline $\begin{array}{l}\text { Received } 02 \text { Dec 2019; } \\
\text { Accepted } 26 \text { Jun 2020; } \\
\text { Published Online } 10 \text { Nov 2020; }\end{array}$ & $\begin{array}{l}\text { enhancing the risk of metastasis by } 4.15 \text {-fold }(95 \% \text { CI: } 0.96-17.85, P=0.055) \text {. The } \\
\text { frequencies of } M T R \text { c. } 2756 \mathrm{~A}>\mathrm{G} \text { and } M T R R \text { c. } 66 \mathrm{~A}>\mathrm{G} \text { variants were not significantly } \\
\text { different among patients and controls. }\end{array}$ \\
\hline & $\begin{array}{l}\text { Conclusion: We observed that the TYMS } 3 \mathrm{R} \text { is a risk allele for susceptibility to } \mathrm{BC} \text { and this } \\
\text { allele may increase the risk of metastasis in } \mathrm{BC} \text { patients. . }\end{array}$ \\
\hline
\end{tabular}

\begin{tabular}{ll}
\hline & Ebrahim Shakiba, Department of Clinical Biochemistry, Medical School, Medical Biology Research Center, \\
Corresponding Information: & Kermanshah, Iran .Email: $\underline{\text { m.shakiba d91@yahoo.com }}$ \\
& Zohreh Rahimi, Department of Clinical Biochemistry, Medical Biology Research Center, Medical School, \\
& Kermanshah, Iran E-mail: zrahimi@kums.ac.ir
\end{tabular}

Copyright (C) 2021. This is an open-access article distributed under the terms of the Creative Commons Attribution- 4.0 International License which permits share, copy and redistribution of the material in any medium or format or adapt, remix, transform, and build upon the material for any purpose, even commercially.

\section{Introduction}

Breast cancer $(\mathrm{BC})$ is the most prevalent cancer among women accounting for $16 \%$ of all cancers in females (1). The increase rate of $\mathrm{BC}$ incidence is $3-4 \%$ in developing countries (2), in which BC occurs around one decade earlier compared to developed countries. Early diagnosis of $\mathrm{BC}$ is critical for treatment of the disease and reducing the mortality rates (3).

Genetic alterations in a multistep process result in normal epithelial cells transformation of mammary into highly malignant cells (4). Population studies suggest a role for gene variants and the mutations as the strong risk factors affecting the individual differences in the BC susceptibility (5).

Since one-carbon metabolism (OCM) has a major role in the DNA synthesis and methylation and interaction between genetic and epigenetic processes, OCM disturbance might have an important role in the etiology of BC (6). The pathway of OCM plays a critical role in the integrity of genome, the gene expression, and the methylation of DNA. So, dysregulation of the pathway might be involved in the risk of BC and its severity (7). Single nucleotide polymorphisms (SNPs) in folate-related genes are suitable candidates for investigating the role of these gene variants in BC risk (8). The thymidylate synthase (TYMS), 5-methyltetrahydrofolate-homocysteine methyltransferase (MTR), and methionine synthase reductase (MTRR) are suitable genes to study the role of variants of genes involved in the metabolism of folate in the $\mathrm{BC}$ risk. 
The 5,10-methylene tetra hydrofolate (THF) is the common substrate for two key enzymes of TYMS and methylenetetrahydrofolate reductase (MTHFR). These enzymes catalyze the conversion of deoxyuridine monophosphate (dUMP) to deoxythymidine monophosphate (dTMP) and flavin adenine dinucleotide (FAD)-dependent reduction of 5,10methylene THF to 5-methyl THF, respectively (9). The dTMP is necessary for DNA synthesis and repair. This reaction plays an important role in intracellular de novo synthesis of thymidylate (10).

The TYMS gene locates at $18 \mathrm{p} 11.32$. The important target for the chemotherapy drugs such as 5fluorouracil (5-FU) is TYMS (11). The most common variation in TYMS (18p11.32) is a double (2R) or triple (3R) 28-bp repeat sequence (rs34743033) in the 5'untranslated region of the promoter enhancer that affects the protein expression in cancer cells (12). In the presence of the TYMS 3R, compared with $2 \mathrm{R}$, there is 2.6-fold more TYMS expression and enhancing the TYMS enzymatic activity.

The MTR gene encodes an enzyme which requires vitamin B12 and catalyzes the remethylation of homocysteine to methionine using 5-methyl THF (12). The MTR gene locates at $1 \mathrm{q} 43$ (13). The common polymorphism of MTR c. $2756 \mathrm{~A}>\mathrm{G}$ (rs1805087) reduces the enzyme activity due to the conversion of aspartate to glycine in the protein, and induces the increase of homocysteine and DNA hypomethylation (12). This polymorphism has been suggested as a good candidate for predisposition to BC risk (13-15).

MTRR enzyme helps in the regeneration of functional MTR by reductive methylation and maintains the active form of MTR (16). The gene of MTRR locates at 5p15.31. The polymorphism of MTRR c.66A>G (rs1801394) results in replacement of isoleucine with methionine at amino acid 22 in the protein (17). The presence of this polymorphism leads to lower affinity of the variant enzyme for methionine synthase (16).

The aim of preset study was to investigate the role of TYMS 2R/3R (rs34743033), MTR c.2756A $>\mathrm{G}$ (rs1805087), and MTRR c. $66 \mathrm{~A}>\mathrm{G}$ (rs1801394) gene variants in susceptibility to BC among a population with Kurdish ethnic background from Western Iran.

\section{Materials and Methods \\ Sample}

We studied $100 \mathrm{BC}$ patients (99 females and 1 male) aged $49.5 \pm 10.2$ years (29-79 years) and 141 healthy females aged 38.7 \pm 9.4 years (range 28-70 years). Diagnosis of BC was based on standard clinical, radiological, and histological parameters. All patients had been admitted to a university hospital affiliated to the Kermanshah University of Medical Sciences (KUMS), Iran. The ethnic background of both patients and controls was Kurdish. The Ethics Committee of KUMS approved the study. All patients and healthy controls agreed to participate in the study and a written informed consent was obtained from all participants prior to conducting the study. The study was in accordance with the principles of the Helsinki II declaration.

\section{Genotyping}

From each participant, $5 \mathrm{ml}$ of whole blood with anticoagulant of Ethylenediaminetetraacetic acid (EDTA) was taken. Using treatment of whole blood with proteinase $\mathrm{K}$ and subsequent phenol-chloroform extraction and ethanol precipitation, genomic DNA was isolated from leukocytes (18).

The concentration and purity of DNA were determined by a Nanodrop spectrophotometer (Thermo Fisher Scientific, Waltham, Massachusetts, USA).

\section{Thymidylate Synthase}

The genomic region of TYMS was amplified by polymerase chain reactions (PCR) using the forward primer 5'GTG GCT CCTGCG TTT CCC CC 3' and the reverse primer 5'CCA AGCTTG GCT CCG AGC CGG CCA CAG GCA TGG CGCGG 3 'to detect the tandem repeat sequences in the $5^{\prime}$-terminal of the TYMS regulatory region (TYMS 2R/3R (rs34743033). The parameters of PCR thermal cycling were: 1 cycle at $94^{\circ} \mathrm{C}$ for $5 \mathrm{~min}, 40$ cycles by $94^{\circ} \mathrm{C}$ for $60 \mathrm{~s}, 63^{\circ} \mathrm{C}$ for $60 \mathrm{~s}$, and $72^{\circ} \mathrm{C}$ for $60 \mathrm{~s}$ followed by final extension at $72^{\circ} \mathrm{C}$ for $10 \mathrm{~min}$. In the presence of homozygotes of double repeat (TYMS 2R2R) a 220-bp fragment is produced, while heterozygotes (TYMS 2R3R) produce two fragments of 220- and 250-bp. In the presence of homozygous TYMS triple repeat (TYMS 3R3R) a fragment with 250-bp is produced (Figure 1) (12).

\section{$M T R$ c. $2756 \mathrm{~A}>\mathrm{G}$}

The MTR c.2756A $>\mathrm{G}$ polymorphism was identified using the forward primer 5'TGT TCCAGA CAG TTA GAT GAA AAT C 3'and 5'GAT CCA AAG CCT TTT ACA CTC CTC 3'as reverse primer. The parameters of PCR thermal cycling were: 1 cycle at $94^{\circ} \mathrm{C}$ for $5 \mathrm{~min}, 40$ cycles by $94^{\circ} \mathrm{C}$ for $60 \mathrm{~s}, 53^{\circ} \mathrm{C}$ for $60 \mathrm{~s}$, and $72^{\circ} \mathrm{C}$ for $60 \mathrm{~s}$ followed by final extension at $72^{\circ} \mathrm{C}$ for $10 \mathrm{~min}$. The $211-\mathrm{bp}$ PCR product (10 to $15 \mu \mathrm{l}$ ) was digested using five units of the Hae III restriction enzyme at $37^{\circ} \mathrm{C}$ overnight. The presence of $M T R$ c. $2756 \mathrm{~A}>\mathrm{G}$ polymorphism creates a recognition sequence for Hae III, which digests the PCR product with 211-bp into 131- and 80-bp fragments (12).

\section{MTRR c.66A $>$ G}

The genotypes of MTRR c.66A $>\mathrm{G}$ was detected by a designed amplification-refractory mutation system (ARMS) method. We designed primers with Oligo7 software that consisted of a primer for wild allele as 5'TGTACCACAGCTTGCTCACTT-3', a primer for mutant allele with the sequence of 5'TGTACCACAGCTTGCTCACTC-3', and a common primer of 5'- TGAAGTGATGAGGAGGTTTC-3'. The parameters of thermal cycler for gene amplification were: 1 cycle at $94^{\circ} \mathrm{C}$ for $5 \mathrm{~min} ; 35$ cycles: denaturation $\left(94^{\circ} \mathrm{C}\right.$ for $35 \mathrm{~s}$ ), annealing $\left(58^{\circ} \mathrm{C}\right.$ for $\left.35 \mathrm{~s}\right)$, extension $\left(72^{\circ} \mathrm{C}\right.$ for $\left.45 \mathrm{~s}\right)$, and final extension $\left(72^{\circ} \mathrm{C}\right.$ for $\left.5 \mathrm{~min}\right)$. The PCR product of wild and/or mutant allele was a fragment with 90-bp. A fragment with 506-bp from prothrombin gene was amplified using the primers 5' GCA CAG ACG GCT GTT CTC TT 3' and 5' ATA GCA CTG GGA GCA TTG AAG C 3', and was used as internal standard (19) (Figure 2). 


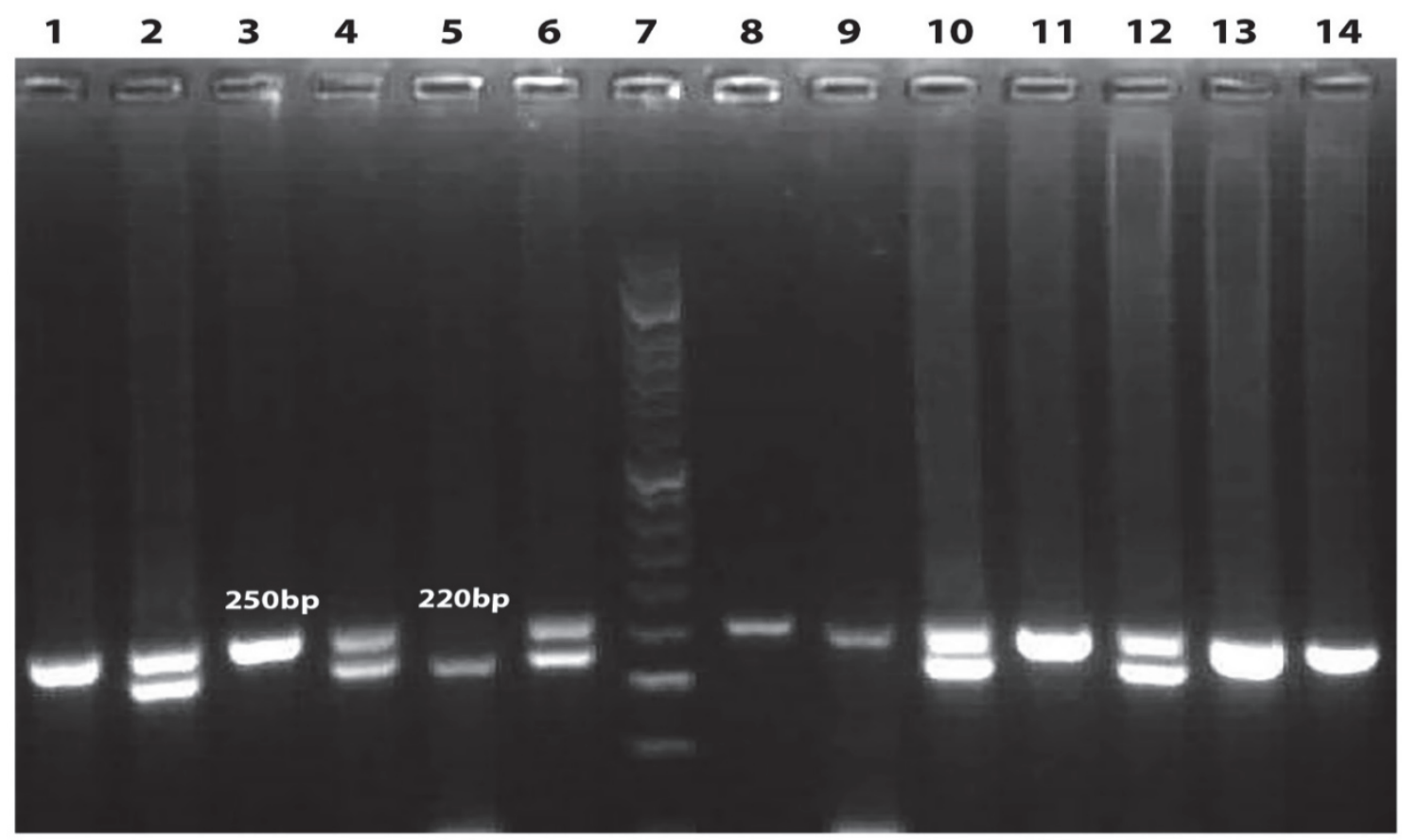

Fig 1. Electrophoresis of TYMS PCR products was done using agarose gel. From left to right columns 1, 3, 8, 9, 11, 13, 14 indicate the genotype of 3R3R, columns 2, 4, 6, 10, 12 demonstrate the genotype of 2R3R and column 5 shows the genotype of 2R2R. Column 7 demonstrates DNA molecular marker.

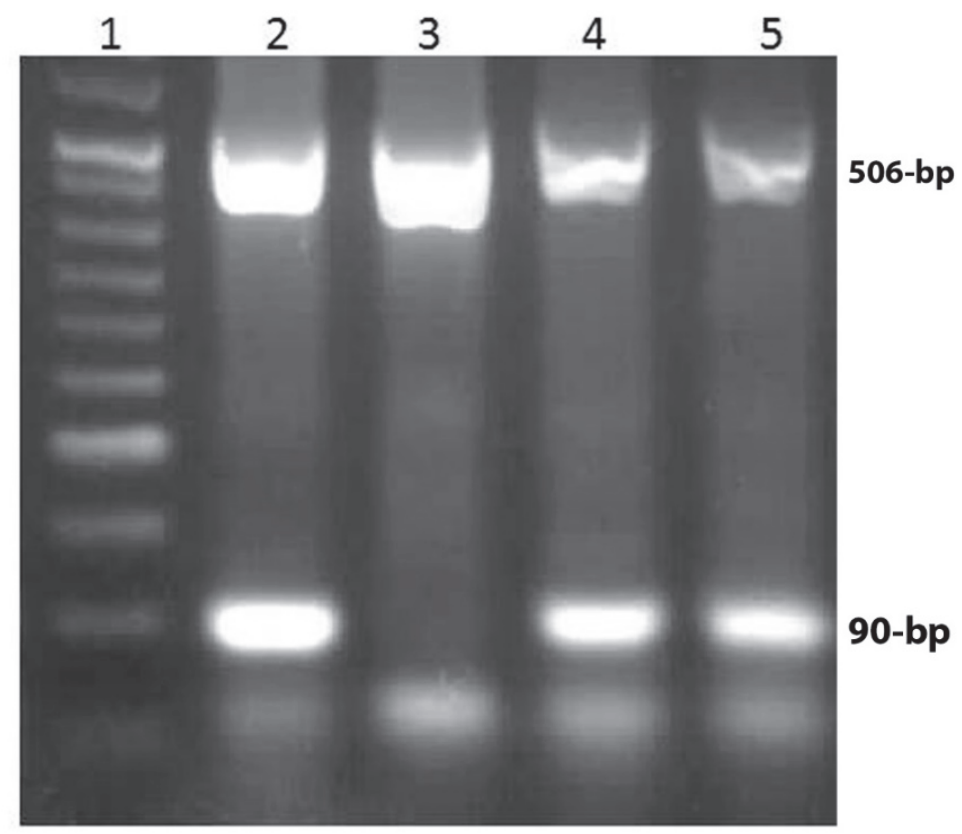

Fig. 2. The pattern of PCR-RFLP products of the $M T R R$ c.66A $>\mathrm{G}$ on agarose gel electrophoresis was obtained. Both lanes 2 and 3 (wild and mutant alleles from the same sample) indicate homozygous MTRR AA genotype. Lanes 4 and 5 (wild and mutant alleles from the same sample) demonstrate MTRR AG genotype. Lane 1 depicts a 50-bp molecular weight.

\section{Statistics}

Using allele frequency calculation method, the frequency of the alleles was calculated. Difference in the alleles and genotypes frequency between both groups and its significance were tested using the $\chi^{2}$ method. Data on quantitative characteristics are explained as mean \pm standard deviation (SD). Odds ratios (OR), that estimates the relative risk of disease, and $95 \%$ confidence interval (CI) were detected using the SPSS software logistic regression. Quantitative data were compared using Student's t test. The level of P-value $<0.05$ was used for the statistical significance. The SPSS version 16 was used for statistical analyses (SPSS Inc., Chicago, IL., USA). 


\section{Results}

Among participants, 39 individuals (39\%) had a family history of cancer among first degree relatives. Based on the available files from 66 patients, there were 51 patients $(77.3 \%)$ with lymph node metastasis. Also, there were 13 patients $(19.7 \%)$ with tumor stage I, 42 patients $(63.6 \%)$ with tumor stage II, and 11 patients $(16.7 \%)$ with tumor stage III. Further, based on available data from files of 82 patients, the histological type of tumor was as $73(89 \%)$ with invasive ductal carcinoma, $8(9.8 \%)$ with invasive lobular carcinoma, and $1(1.2 \%)$ with in situ type.

The genotypes and alleles frequency of TYMS 2R/3R in patients with $\mathrm{BC}$ and controls are indicated in Table 1.
TYMS 28-bp repeat 2R2R, as a reference genotype, was identified in $9 \mathrm{BC}$ patients $(9 \%), 2 \mathrm{R} 3 \mathrm{R}$ was observed in 38 patients $(38 \%)$, and $3 \mathrm{R} 3 \mathrm{R}$ was identified in 53 patients $(53 \%)$. The frequencies of $2 R 2 R, 2 R 3 R$, and 3R3R genotypes in 141 healthy individuals were 20.6, 63.8 , and $15.6 \%$, respectively. The frequency of $2 \mathrm{R}$ allele among patients and healthy individuals were 28 and $52.5 \%$, respectively (Table 1 ). The frequency of $3 \mathrm{R}$ allele was $72 \%$ in patients and $47.5 \%$ in controls $(P<0.001)$. Higher frequency of $3 \mathrm{R}$ allele in patients enhanced the $\mathrm{BC}$ risk $(\mathrm{OR}=2.84,95 \% \mathrm{CI}: 1.92-4.18$, $P<0.001)$ (Table 1).

Table 1. Distribution of TYMS 2R/3R polymorphism in breast cancer patients and healthy individuals.

\begin{tabular}{|c|c|c|c|c|}
\hline TYMS & $\begin{array}{c}\text { Patients } \\
\mathbf{n = 1 0 0} \\
\mathbf{n}(\mathbf{\%})\end{array}$ & $\begin{array}{c}\text { Controls } \\
\mathbf{n}=\mathbf{1 4 1} \\
\mathbf{n}(\mathbf{\%})\end{array}$ & $\begin{array}{c}\chi^{2}, \mathbf{p} \\
\text { OR (95\% CI), } \boldsymbol{P}\end{array}$ \\
\hline 2R 2R & $9(9)$ & $29(20.6)$ & - & - \\
\hline 2R 3R & $38(38)$ & $90(63.8)$ & $32.1,<0.001$ & $0.175(0.094-0.32),<0.001$ \\
\hline 3R 3R & $53(53)$ & $22(15.6)$ & $22.5,<0.001$ & $2.78(1.77-4.36),<0.001$ \\
\hline Allele & & & & $2.84(1.92-4.18),<0.001$ \\
\hline 2R & $56(28)$ & $148(52.5)$ & $28.7,<0.001$ & \\
\hline 3R & $144(72)$ & $134(47.5)$ & & \\
\hline
\end{tabular}

Overall $\chi^{2}=38.6$, P-value $<0.001$ comparing three genotypes

In $\mathrm{BC}$ patients with metastasis, a significantly higher frequency of TYMS 3R3R ( $\mathrm{n}=28,60.9 \%)$ was detected compared to 2R3R ( $\mathrm{n}=18,39.1 \%)$. The presence of TYMS 3R/3R, compared to $2 \mathrm{R} / 3 \mathrm{R}$, tended to elevate the risk of metastasis by 4.15 -fold $(95 \% \mathrm{CI}$ : 0.96-17.85, $P=0.055$ )

Distribution of MTR 2756A $>\mathrm{G}$ genotypes and alleles in patients and controls are depicted in Table 2. The common genotype of MTR AA was found in 59 patients (60.2\%), the AG genotype in 35 patients $(35.7 \%)$ and the homozygous genotype of GG were identified in 4 patients (4.1\%). In healthy controls, 75 subjects $(53.2 \%)$ had the AA genotype, 52 subjects $(36.9 \%)$ had the AG genotype, and 14 subjects $(9.9 \%)$ had the GG genotype. The frequency of $\mathrm{G}$ allele was $21.9 \%$ in patients and $28.4 \%$ in controls $(P=0.1)$ (Table 2$)$.

Table 2. Comparison of MTR c. $2756 \mathrm{~A}>\mathrm{G}$ genotypes and alleles between patients and control group.

\begin{tabular}{|c|c|c|c|}
\hline $\begin{array}{c}\text { MTR } \\
\text { c.2756A }>\text { G }\end{array}$ & $\begin{array}{c}\text { Patients } \\
\mathbf{n = 9 8} \\
\mathbf{n}(\mathbf{\%})\end{array}$ & $\begin{array}{c}\text { Controls } \\
\mathbf{n = 1 4 1} \\
\mathbf{n}(\%)\end{array}$ \\
\hline Genotype & $59(60.2)$ & $75(53.2)$ & \\
\hline AA & $35(35.7)$ & $52(36.9)$ & $0.36,0.54$ \\
\hline AG & $4(4.1)$ & $14(9.9)$ & $3.19(0.074)$ \\
\hline GG & & & $2.64,0.1$ \\
\hline Allele & $153(78.1)$ & $202(71.6)$ & \\
\hline A & $43(21.9)$ & $80(28.4)$ & \\
\hline G & & \\
\hline
\end{tabular}

Overall $\chi^{2}=3.25,0.19$ comparing three genotypes 
The frequency of genotypes and alleles of MTRR $66 \mathrm{~A}>\mathrm{G}$ in patients and healthy individuals are depicted in Table 3. The frequency of MTRR GG genotype was $16.1 \%$ in patients compared to $13.5 \%$ in controls. The frequency of $M T R R \mathrm{G}$ allele was not significantly different among BC patients and controls ( $49 \%$ vs. $51.4 \%, P=0.65$ ) (Table 3 ).

Table 3. The frequency of $M T R R$ c. $66 \mathrm{~A}>\mathrm{G}$ polymorphism in breast cancer patients compared to control group.

\begin{tabular}{|c|c|c|c|}
\hline $\begin{array}{c}\text { MTRR } \\
\text { c.66A>G }\end{array}$ & $\begin{array}{c}\text { Patients } \\
\mathbf{n}=99 \\
\mathbf{n}(\%)\end{array}$ & $\begin{array}{c}\text { Controls } \\
\mathbf{n}=141 \\
\mathbf{n}(\%)\end{array}$ \\
\hline Genotype & $18(18.2)$ & $15(10.6)$ & $\chi^{2}, P$ \\
\hline AA & $65(65.7)$ & $107(75.9)$ & $2.88,0.09$ \\
\hline AG & $16(16.1)$ & $19(13.5)$ & $0.36,0.54$ \\
\hline GG & & & $0.19,0.65$ \\
\hline Allele & $101(51)$ & $137(48.6)$ & \\
\hline A & $97(49)$ & $145(51.4)$ & \\
\hline
\end{tabular}

Overall $\chi^{2}=3.28$, P-value $=0.19$

\section{Discussion}

TYMS is a necessary enzyme for biosynthesis of DNA. In the presence of three copies of tandem repeats (TYMS 3R), compared with two copies of tandem repeats (2R), there is higher TYMS expression enhancing the TYMS enzymatic activity (20).

In the present study we detected a significantly increased risk of $\mathrm{BC}$ by 2.84 -fold in the presence of TYMS 3R. A better response to 5-FU therapy and increased overall survival has been observed in patients with the genotype of $T Y M S 2 \mathrm{R} / 2 \mathrm{R}$ or $T Y M S 2 \mathrm{R} / 3 \mathrm{R}$ compared to TYMS 3R/3R (20). The role of ethnicity in different frequency of gene's variants involved in the metabolism of folate and methionine has been indicated (12). In Mexican females, TYMS 2R/3R was not related to the risk of $\mathrm{BC}$ (21). Also, in three studies from Asia, Japan, China, and India, TYMS polymorphism did not influence the risk of BC (22-24). A meta-analysis indicated that TYMS $2 \mathrm{R} / 3 \mathrm{R}$ might increase the risk of $\mathrm{BC}$ in Caucasian females and suggested the role of ethnic background for TYMS variants in BC susceptibility (25).

There was no significant difference in the distribution of $M T R 2756 \mathrm{~A}>\mathrm{G}$ variants between $\mathrm{BC}$ patients and healthy individuals. The role of this polymorphism in the $\mathrm{BC}$ risk is controversial. Among southeastern Asians, three studies from china found a significant association between $M T R 2756 \mathrm{~A}>\mathrm{G}$ variants and $\mathrm{BC}$ risk (26-28). However, in reports from China, Japan, and India, no association was detected between MTR 2756A $>\mathrm{G}$ polymorphism with the risk of $\mathrm{BC}(22$, $24,29)$. In a meta-analysis, this polymorphism was not correlated with the $\mathrm{BC}$ risk considering all populations. However, subgroup analysis indicated that the $2756 \mathrm{G}$ allele was correlated with a reduced risk in Caucasians (30). The reasons for various results obtained in Asians (the lack of association between this polymorphism with the risk of BC) and in Europeans (decreased risk of BC in the presence of $\mathrm{G}$ allele) could be attributed to genetic background diversity (ethnicity) and gene-environment interactions. Other factors that might explain the heterogeneity of results among the existing studies include: the differences in sample size, the different genetic background of studied populations, the differences in study design and conduct, the interaction between gene-gene and gene-environment, and the absence of stratification of data according to folate intake (30).

In our study, we observed the lack of association between MTRR $66 \mathrm{~A}>\mathrm{G}$ polymorphism with the risk of BC. The MTRR $66 \mathrm{~A}>\mathrm{G}$ variants were not associated with the risk of BC among Indian, American, Canadian, and Syrian females (24, 31-33). The Shanghai Breast Cancer Study among Chinese female patients reported the absence of a significant association between the risk of $\mathrm{BC}$ and MTR 2756A $>\mathrm{G}$ or MTRR $66 \mathrm{~A}>\mathrm{G}$ genotypes (34). In a meta-analysis conducted by $\mathrm{Hu}$ et al. (16) considering 7,097 cases and 7,710 controls, the MTRR $66 \mathrm{~A}>\mathrm{G}$ variants were not associated with $\mathrm{BC}$ risk. But among Chinese female patients with BC, MTRR had a protective role and decreased the risk of $\mathrm{BC}$ (35). Also, in a meta-analysis by Naushad et al. (9) which consisted of 62 case-control studies from 17 different populations including $18,117 \mathrm{BC}$ cases and 23,573 healthy controls, the MTR 2756A $>\mathrm{G}$ indicated a borderline protective role against $\mathrm{BC}(\mathrm{OR}=0.78,95 \% \mathrm{CI}$ : $0.75-0.82)$. In silico analysis revealed that the MTR 2756A $>\mathrm{G}$ could induce benign damage to the MTR protein while the MTRR $66 \mathrm{~A}>\mathrm{G}$ indicated a deleterious effect on MTRR protein. Regarding the action of MTR and MTRR together in a 1:1 stoichiometric ratio to produce the holoenzyme 
complex, it seems the variant alleles of MTR and MTRR act in synergy in modulation of BC risk (34).

\section{Conclusion}

The results of the present study indicates that the TYMS 3R allele may be a risk factor for $\mathrm{BC}$ development in our population. Also, in the presence of $T Y M S$ 3R/3R, a tendency and increased risk for BC metastasis may exist. However, MTR 2756A $>\mathrm{G}$ and MTRR 66A $>\mathrm{G}$ variants are not significantly associated with the risk of $\mathrm{BC}$ development. In addition, there is no significant association between these genetic variants with the histopathological characteristics of the patients.

\section{Acknowledgements}

This work was performed in partial fulfillment of the requirements for MSc degree of Maryam Bozorgi Zarini and was financially supported by a grant from Vice Chancellor for Research of Kermanshah University of Medical Sciences, Kermanshah, Iran.

\section{Conflict of Interest}

The authors confirm that there are no known conflicts of interest associated with this publication, and there has been no significant financial support for this work that could have influenced its outcome.

\section{References}

1. Rahimi Z, Yari K, Rahimi, Z. Matrix Metalloproteinase$9-1562 \mathrm{~T}$ allele and its combination with MMP-2 -735 $\mathrm{C}$ allele are risk factors for breast cancer. Asian Pac J Cancer Prev. 2015; 16:1175-1179. [DOI:10.7314/APJCP.2015.16.3.1175] [PMID]

2. Yari K, Rahimi Z, Moradi MR, Rahimi Z. The MMP-2 $-735 \mathrm{C}$ allele is a risk factor for susceptibility to breast cancer. Asian Pac J Cancer Prev. 2014; 15: 6199-6203. [DOI:10.7314/APJCP.2014.15.15.6199] [PMID]

3. Rahimi Z, Kasraei R, Najafi F, et al. Cancer notification at a referral hospital of Kermanshah, Western Iran (2006-2009). Asian Pac J Cancer Prev. 2015; 16: 133137. [DOI:10.7314/APJCP.2015.16.1.133] [PMID]

4. Waseem M, Hussain S.R, Kumar S, et al. Association of MTHFR (C677T) gene polymorphism with breast cancer in north India. Biomarkers in Cancer. 2016; 8 111-117. [DOI:10.4137/BIC.S40446] [PMID] [PMCID]

5. Yari K, Rahimi Z, Payandeh M, Rahimi Z. MMP-7 A$181 \mathrm{G}$ polymorphism in breast cancer patients from Western Iran. Breast Care (Basel). 2015; 10:398-402. [DOI:10.1159/000442231] [PMID] [PMCID]

6. Chen J, Gammon M.D Chan W, et al. One-carbon metabolism, MTHFR polymorphisms, and risk of breast cancer. Cancer Res. 2005; 65:1606-1614. [DOI:10.1158/0008-5472.CAN-04-2630] [PMID]
7. Naushad S.H.M, Pavani A, Rupasree Y, et al. Association of aberrations in one-carbon metabolism with molecular phenotype and grade of breast cancer. Mol Carcinog. 2012; 51: E32-41. [DOI:10.1002/mc.21830] [PMID]

8. Abdulrahman G.O. Jr, Rahman G.A. Epidemiology of breast cancer in Europe and Africa. J Cancer Epidemiol. 2012; 2012: 915610. [DOI:10.1155/2012/915610] [PMID] [PMCID]

9. Naushad SM, Divya C, Ramaiah MJ, Hussain T, Alrokayan SA, Kutala VK. Population-level diversity in the association of genetic polymorphisms of onecarbonmetabolism with breast cancer risk. J Community Genet. 2016; 7:279-290. [DOI:10.1007/s12687-0160277-1] [PMID] [PMCID]

10. Cheng CW, Yu JC, Huang CS, Shieh JC, Fu YP, Wang HW, Wu PE, Shen CY. Polymorphism of cytosolic serine hydroxymethyltransferase, estrogen and breast cancer risk among Chinese women in Taiwan. Breast Cancer Res Treat. 2008;111(1):145-55. [DOI:10.1007/s10549-007-9754-x] [PMID]

11. DeRoo LA, Bolick SC, Xu Z, Umbach DM, Shore D, Weinberg CR, Sandler DP, Taylor JA. Global DNA methylation and one-carbon metabolism gene polymorphisms and the risk of breast cancer in the Sister Study. Carcinogenesis. 2014;35(2):333-8. [DOI:10.1093/carcin/bgt342] [PMID] [PMCID]

12. Rahimi Z, Ahmadian Z, Akramipour R, Vaisi-Raygani A, Rahimi Z, Parsian A. Thymidylate synthase and methionine synthase polymorphisms are not associated with susceptibility to childhood acute lymphoblastic leukemia in Kurdish population from Western Iran. Mol Biol Rep. 2012; 39:2195-200. [DOI:10.1007/s11033011-0968-y] [PMID]

13. Ozen F, Erdis E, Sik E, Silan F, Uludag A, Ozdemir O. Germ-line MTHFR C677T, FV H1299R and PAI-1 $5 \mathrm{G} / 4 \mathrm{G}$ variations in breast carcinoma. Asian Pac J Cancer Prev. 2013;14, 2903-2908. [DOI:10.7314/APJCP.2013.14.5.2903] [PMID]

14. Akilzhanova A, Nurkina Z, Momynaliev K, et al. Genetic profile and determinants of homocysteine levels in Kazakhstan patients with breast cancer. Anticancer Res. 2013; 33:4049-4059.

15. Mohammad N.S, Yedluri R., Addepalli P, Gottumukkala S.R, Digumarti R.R, Kutala V.K. Aberrations in one-carbon metabolism induce oxidative DNA damage in sporadic breast cancer. Mol Cell Biochem. 2011; 349:159-167. [DOI:10.1007/s11010010-0670-8] [PMID]

16. Hu S, Liu HC, Xi SM. Methionine Synthase Reductase A66G Polymorphism is not Associated with Breast Cancer Susceptibility-a Meta-analysis. Asian Pac J Cancer Prev. 2014;15(7):3267-71. [DOI:10.7314/APJCP.2014.15.7.3267] [PMID]

17. López-Cortés A, Echeverría $\mathrm{C}$, Oña-Cisneros $\mathrm{F}$, Sánchez ME, Herrera C, Cabrera-Andrade A, Rosales F, Ortiz M, Paz-y-Miño C. Breast cancer risk associated with gene expression and genotype polymorphisms of the folate-metabolizing MTHFR gene: a case-control study in a high altitude Ecuadorian mestizo population. Tumor Biol. 2015;36(8):6451-61. [DOI:10.1007/s13277-015-3335-0] [PMID] 
18. Rahimi Z, Mozafari H, Shahriari-Ahmadi A, Alimogaddam K, Ghavamzadeh A, Aznab M, et al. Deep venous thrombosis and thrombophilic mutations in western Iran: association with factor V Leiden. Blood Coagul Fibrinolysis. 2010;21(5):385-8 [DOI:10.1097/MBC.0b013e328330e69a] [PMID]

19. Huber S, McMaster KJ, Voelkerding KV. Analytical evaluation of primer engineered multiplex polymerase chain reaction-Restriction fragment length polymorphism for detection of factor $\mathrm{V}$ Leiden and prothrombin G20210A. J Mol Diagn. 2000;2(3):153-7. [DOI:10.1016/S1525-1578(10)60631-9]

20. Nalejska E, Mączyńska E, Lewandowska MA. Prognostic and predictive biomarkers: tools in personalized oncology. Mol Diagn Ther. 2014;18(3):273-84. [DOI:10.1007/s40291-013-0077-9] [PMID] [PMCID]

21. Quintero-Ramos A, Gutiérrez-Rubio S.A, Del ToroArreola A, et al. Association between polymorphisms in the thymidylate synthase gene and risk of breast cancer in a Mexican population. Genet Mol Res 2014; $13: 8749$ 8756. [DOI:10.4238/2014.October.27.16] [PMID]

22. Suzuki T, Matsuo K, Hirose K, Hiraki A, Kawase T, Watanabe M, Yamashita T, Iwata H, Tajima K. Onecarbon metabolism-related gene polymorphisms and risk of breast cancer. Carcinogenesis. 2008;29(2):35662. [DOI:10.1093/carcin/bgm295] [PMID]

23. Zhai X, Gao J, Hu Z, Tang J, Qin J, Wang S, Wang X, Jin G, Liu J, Chen W, Chen F. Polymorphisms in thymidylate synthase gene and susceptibility to breast cancer in a Chinese population: a case-control analysis. BMC Cancer. 2006;6(1):138. [DOI:10.1186/14712407-6-138] [PMID] [PMCID]

24. Mohammad NS, Yedluri R, Addepalli P, Gottumukkala SR, Digumarti RR, Kutala VK. Aberrations in onecarbon metabolism induce oxidative DNA damage in sporadic breast cancer. Mol Cell Biochem. 2011;349(12):159-67. [DOI:10.1007/s11010-010-0670-8] [PMID]

25. Wang J, Wang B, Bi J, Di J. The association between two polymorphisms in the TYMS gene and breast cancer risk: a meta-analysis. Breast Cancer Res. 2011;128(1):203-9. [DOI:10.1007/s10549-010-1314-0] [PMID]

26. Jiang-hua Q, De-chuang J, Zhen-duo L, Shu-de C, Zhenzhen L. Association of methylenetetrahydrofolate reductase and methionine synthase polymorphisms with breast cancer risk and interaction with folate, vitamin B 6, and vitamin B 12 intakes. Tumor Biol.
2014;35(12):11895-901. [DOI:10.1007/s13277-0142456-1] [PMID]

27. Yu L, Chen J. Association of MHTFR Ala222Val (rs1801133) polymorphism and breast cancer susceptibility: An update meta-analysis based on 51 research studies. Diagn Pathol. 2012;7(1):171. [DOI:10.1186/1746-1596-7-171] [PMID] [PMCID]

28. Wu XY, Ni J, Xu WJ, Zhou T, Wang X. Interactions between MTHFR C677T-A1298C variants and folic acid deficiency affect breast cancer risk in a Chinese population. Asian Pac J Cancer Prev. 2012;13(5):2199206. [DOI:10.7314/APJCP.2012.13.5.2199] [PMID]

29. He JM, Pu YD, Wu YJ, Qin R, Zhang QJ, Sun YS, Zheng WW, Chen LP. Association between dietary intake of folate and MTHFR and MTR genotype with risk of breast cancer. Genet Mol Res. 2014;13(4):892531. [DOI:10.4238/2014.October.31.7] [PMID]

30. Zhong S, Xu J, Li W, Chen Z, Ma T, Zhao J. Methionine synthase $\mathrm{A} 2756 \mathrm{G}$ polymorphism and breast cancer risk: an up-to-date meta-analysis. Gene. 2013;527(2):510-5. [DOI:10.1016/j.gene.2013.06.054] [PMID]

31. Xu X, Gammon MD, Zhang H, Wetmur JG, Rao M, Teitelbaum SL, Britton JA, Neugut AI, Santella RM, Chen J. Polymorphisms of one-carbon-metabolizing genes and risk of breast cancer in a population-based study. Carcinogenesis. 2007;28(7):1504-9. [DOI:10.1093/carcin/bgm061] [PMID]

32. Kotsopoulos J, Zhang WW, Zhang S, McCready D, Trudeau M, Zhang P, Sun P, Narod SA. Polymorphisms in folate metabolizing enzymes and transport proteins and the risk of breast cancer. Breast Cancer Res Treat. 2008;112(3):585-93. [DOI:10.1007/s10549-008-98956] [PMID]

33. Lajin B, Sakur AA, Ghabreau L, Alachkar A. Association of polymorphisms in one-carbon metabolizing genes with breast cancer risk in Syrian women. Tumor Biol. 2012;33(4):1133-9. [DOI:10.1007/s13277-012-0354-y] [PMID]

34. Shrubsole MJ, Gao YT, Cai Q, Shu XO, Dai Q, Jin F, Zheng W. MTR and MTRR polymorphisms, dietary intake, and breast cancer risk. Cancer Epidemiol Biomarkers Prev. 2006 Mar 1;15(3):586-8. [DOI:10.1158/1055-9965.EPI-05-0576] [PMID]

35. Luo WP, Li B, Lin FY, Yan B, Du YF, Mo XF, Wang $\mathrm{L}$, Zhang CX. Joint effects of folate intake and onecarbon-metabolizing genetic polymorphisms on breast cancer risk: a case-control study in China. Sci Rep. 2016;6(1):1-1. [DOI:10.1038/srep29555] [PMID] [PMCID] 